\title{
'Student-Centered Volunteering' in the University System: The Case of CCE at Oregon State University
}

\author{
Assoc. Prof. Dr. Filiz Otay Demir ${ }^{1}$ \\ Maltepe University, Istanbul, Turkey \\ Email: filizotay@maltepe.edu.tr \\ Prof. Dr. Sunil Khanna \\ Oregon State University, Oregon, USA \\ Email: sunil.khanna@oregonstate.edu
}

\section{Assist. Director for CCE, Emily Bowling}

Oregon State University, Oregon, USA

Email: emily.bowling@oregonstate.edu

\section{Doi:10.5901/jesr.2015.v5n1p103}

\begin{abstract}
Today, universities wish to be defined as motivators that work interactively with all parts of the society and that pioneer many social changes. Accordingly, universities are expected to determine and execute their education policies in an interactive network based on the needs of all segments of the society. In this context, it is necessity to discuss how universities deliver on their public purpose, and improve infrastructure for volunteer, civic engagement, and other forms of community engagement in and outside the classroom. This descriptive study focuses on the institution and practice of volunteering among students and staff in institutions of higher education. It aims to discover some of the effective management strategies to streamline volunteering efforts, especially the efforts that adopt a student-centered approach. The study also examines how volunteering opportunities are organized and funded within the university system and, how students are motivated and supervised for volunteering activities. The study uses current volunteering practices, which to be managed centrally by Center for Civic Engagement' at Oregon State University in USA as a "best practice" model to promote volunteering among students.
\end{abstract}

Keywords: volunteerism, civic engagement, student-centered approach, university education.

\section{Introduction}

Universities, as well as being organizations providing education and producing scientific research, are responsible for identifying existing or potential problems, and producing and applying solution proposals within its environment. The area of responsibility expected from universities is that it should cover all the problems and developments in its environment and society. Among the classic university roles, the social engagement of universities and their impact on civil society should emphasize their civic role, their social responsibility and their role in developing a strong society. Fleur de Lys C. Cupino (2006:42) says "we look at education as an entry point to community development interventions, working hand-inhand with other community institutions like NGOs, the barrages (local government councils), the religious organizations, the public school system, and other organizations." Giroux (2009) also defines education as a space that exists outside of the classroom in the midst of pluralities, and argues that education has the capacity to bring social change as long as it is related to the realities of everyday life. "Higher education should play a leading role in educating students for good citizenship, by enhancing students' learning experience to create self-motivated learners who become skilled and committed civic participants" (Marullo \& Edwards, 2000).

In the contemporary sense, universities wish to be defined as motivator agents that work interactively with other parts of the society and that pioneer many social changes. Therefore, universities are expected to determine and execute

${ }^{1}$ Corresponding author Assoc.Prof.Dr. Filiz Otay Demir was supported by TUBITAK (The Scientific and Technological Research Council of Turkey) financially within 'Research Fellowship Program for International Researchers' to do this research at the abroad (USA). 
their education policies in an interactive network based on the needs of all parts segments of the society including industry. Importance of the relationship between the community and university becomes apparent in the process of developing standards to ensure the compatibility of higher education with the European Union standards. The last of the relevant EU declarations, Bologna Declaration, sets up specific targets and defines these targets with reference to certain processes. "Declaration ends with the decision of strengthening higher education through cooperations among governments and European NGOs that operate within the area of education" (Süngü, 2008). It appears that different education plans redefined by Bologna declaration requires interaction among different sections of the society. Especially volunteering activities and social projects are significant opportunities for universities with regard to working with the communities and contributing to the society. By embracing a student-centered approach, universities will encourage and guide their students to create independent social projects and take responsibility by volunteering for related works, and in turn provide students with opportunities to develop civic knowledge, literacy, skills, and values in order to lives as active citizens engaged in issues of public concern. University students working as volunteers make enormous contributions to their communities, to charitable and cultural organizations, and to individuals who depend on their help.

Cultural, economic and political contexts effect the size and scope of the non-profit sector and the amount and type of volunteering. Practices of student volunteering are also influenced by these factors. In many Western countries, particularly in USA, England and Canada, the non-profit sector has developed and the knowledge and experience regarding volunteering activities has advanced; therefore, volunteering activities in universities in these countries have gained a formal structure. At Oregon State University, USA, volunteering activities have already been established. Many remarkable volunteer and philanthropic works are being carried out by both the independent student organizations and the Center for Civic Engagement (CCE). Volunteering structure and the CCE, in which co-curricular civic engagement activities is centralized, function as an umbrella for all of the non-credit bearing volunteering activities in Oregon State University. The CCE facilitates many activities that create awareness in order to increase students' civic and community involvement; and make them think about how they can contribute to and participate in activities, and even create their own activities. Moreover, the Center manages and supports volunteering activities by taking over the responsibility for informing students on volunteering, directing students to communities and organizations that are in need of volunteers, bringing community representatives and students together, monitoring and bettering the process and facilitating student participation. This study offers a detailed case analysis with regard to the student-centered volunteering structure and activities managed by the CCE in Oregon State University, and how they are established and managed. The analysis will contribute to an important study since it will provide a successful benchmark for volunteering activities and offer a means of sharing experience. It is significant for academicians who study on university education and student volunteerism also audiences who relevant of volunteering, civil engagement and social responsibility.

\section{Context of the Case}

\subsection{What is volunteering?}

Volunteering is an activity focused on helping others, it does not require any obligation, and it is not done for pecuniary gain or materialistic aims. Volunteer work is defined as "unpaid volunteering work provided to parties to whom the worker owes no contractual, familial, or friendship obligations." (Tilly \& Tilly, 1994: 291). Consistent with the literature, volunteer work is seen as a productive activity that involves giving time freely for the benefit of others and as "the contributions of services, goods or time to help accomplish some desired end without substantial coercing or direct remuneration." (Smith, 1981: 33). Volunteerism involves long-term, planned, prosocial behaviors that benefit strangers, and it usually occurs in an organizational setting. (Penner, 2002:59). For university students, volunteerism involves non-compulsory, unpaid, externally oriented, formal activities taking place inside and outside the university setting.

\subsection{Types of volunteer organizations and programs}

Volunteer Organizations and Programs are categorized using five criteria (organization functions; organizational structure; organizational demographic; organizational composition; and institutional sponsorship) by Fisher and Schaffer (1993:29-32), details of which are provided below: Organization functions focusing on the volunteer program activities and defining its mission and purposes are classified in three groups: public-oriented; product-oriented; and serviceoriented. Public-oriented functions, just as in many other education programs, aims to improve the target group. Fundraising programs or charity drive (medicine, book, food, clothes etc.) programs serve as an example of product-oriented 
functions. Service-oriented functions, on the other hand, include hospital services, or immediate services such as providing food and accommodation for the homeless. Another way to classify the functions of volunteer organizations is in terms of who is helped or served by the activities of volunteers: elderly, children, teenagers, women, special populations (ethnic minorities or persons with specific disabilities), or the general public. Organizational Structure criterion is explained using sub-criteria which are, the institutional framework; the staff structure; and the institutional affiliation. Institutional framework focuses on whether volunteer programs are established as independent structures or as a part of another institution. Staff Structure category deals with the paid and non-paid employees, their ratios and numbers in the organization. Organizational structure also differs by institutional affiliation. Whether or not the organization has other affiliations is considered a structural characteristic. (Fisher and Schaffer, 1993:29-32). Other ways to characterize organizations are 'Organizational Demographics', 'Organizational Composition' and 'Institutional Sponsorship'. Organizational demographic criterion deals with characteristics specific to the organization such as the number of the volunteers in the organization, budget, location and the age of program. Organizational Composition is in terms of their participants. Some volunteer organizations prefer to work with specific groups as volunteers, while others might be willing to work with all candidates. Institutional Sponsorship criterion is based on whether organizations are supported by any private sector, government and religious organizations, or the third sector.

\subsection{A typology of volunteer roles}

Two basic types of service were recognized in the volunteerism: Administrative and operational. The most frequently mentioned is the administrative volunteer who serves on a committee or board of directors, and who participates at the 'policy level' in the planning determination and evaluation of the board framework (Naylor, 1973: 25). There are many operational roles such as creating organization bulletin, execute fund-raising campaigns, working individually with groups for which services are provided, and manage office duties. The distinguishing factor in the work of operational volunteers is the supervision of their work by staff (Naylor, 1973: 25). Considering of the supervision by staff' factor, it could be easily foresee that university students would assume operational roles in communities, and they would be included in a training program by their staff or senior volunteers. They would have to wait until they have required experience in order to undertake administrative roles. Naturally, for seasonal or one-time volunteers these requirements would not be in question. In independent student organizations established to execute volunteering activities in the university system, university students may assume both administrative and operational roles.

\subsection{Why university students 'should' volunteer}

Volunteer motivations subject-matter is a very complicated and intriguing area with many reasons. Fischer and Schaffer (1993: 43) identified eight categories of motivations: altruistic, ideological, egoistic, material/reward, status/reward, social relationship, leisure time, and personal growth motivations. Huston et al. (2010:353) categorized clustering motivations to volunteer under three headings, namely 'altruism', 'egoism', and 'investment in human capital'. Traditionally volunteer motivations have been assumed to be altruistic. The evidence in the last 30 years proves the existence of a motivational shift in societal and individual trends towards egocentrism and self-development. People are now seeking growth and self-satisfaction from their volunteer experiences, in addition to the more traditionally hypothesized motivations of helping others. (Sergent and Sedlacek, 1990: 255).

"Due to increasing pressure and competition to achieve that youth face today, especially in North America, the payoff of volunteering and its use in résume building may be a powerful drive that can dominate other motives in the decision to volunteer" (Handy et al., 2010). Menchik and Weisbrod (1987) said that individuals engage in volunteer activities to raise future earnings on the labor market. In other words, volunteer practices not only present benefits in terms of professional experience but also act as significant supporters in acquiring social contacts to be used in the future. The motivations defined as extrinsic reasons or investment in human capital and their social network.

\section{Methodology}

The study is organized as qualitative document scanning (web sites of the Center of Civic Engagement, handouts of volunteering opportunities, posters, reports, newsletters, promotional films, photographs, presentations provisions, communities' posters and bulletins, etc.) and interviews with volunteer managers and student staff members of the Center for Civic Engagement. The data collection process was accomplished in August 2014. At this study, mixed 
methodology which composed of document scanning and interview was chosen to describe of the case profoundly, and to aimed to avoid taking superficial approaches.

\title{
4. The Case of the Center for Civic Engagement (CCE) at Oregon State University (OSU)
}

This study, which aims to create a better understanding of student-centered volunteering structure in OSU, presents its findings in two main sections. The first section focuses on Civic Engagement Education Model, and aims to explain how this education model is carried out in OSU through the CCE. The second main section, on the other hand, illustrates the relationship between communities and the CCE, how the projects carried out in collaboration with communities supported by the CCE, and how student engagement works.

\subsection{Civic engagement notion of CCE}

The CCE explains the civic engagement notion based on two definitions by Barbara Jacoby and Thomas Ehrlich. These two civic engagement definitions and the CCE's mission are mentioned below:

\begin{abstract}
"Civic engagement means working to make a difference in the civic life of our communities and developing the combination of knowledge, skills, values, and motivation to make that difference. It means promoting the quality of life in a community, through both political and nonpolitical processes" (Ehrlich, 2000).

"Civic engagement is acting upon a heightened sense of responsibility to one's communities. This includes a wide range of activities, including developing civic sensitivity, participation in building civil society, and benefiting the common good. Civic engagement encompasses the notions of global citizenship and interdependence. Through civic engagement, individuals-as citizens of their communities, their nations, and the world-are empowered as agents of positive social change for a more democratic world" (Jacoby, 2009).
\end{abstract}

The Center for Civic Engagement's mission is to facilitate students' engagement with communities that promote shared knowledge and inspire positive change and societal contributions. In partnership with community-based organizations, the Center for Civic Engagement (CCE) facilitates meaningful service, community engagement, and educational programs. Thus, the Center for Civic Engagement strives to: engage students in service, philanthropy, and activism based work; meet diverse community-identified needs; create positive change in local and global communities; enhance students' knowledge of self and sense of place; inspire students to have a heightened sense of responsibility for the communities around them; provide experiential learning opportunities, and foster active community engagement and social responsibility (CCE's mission description). The CCE includes "inspire positive change in local and global issues" in its mission definition, which refers to a wide range of scope and explains civic engagement notion thoroughly in six different categories. The first of these and the most popular one is community service and volunteering. Community service and volunteerism addresses the immediate needs of local social and ecological communities; Community development identifies and increases the human or economic assets of a community through philanthropy and fundraising, community building, civic leadership, grassroots alliances and other means. Activism mobilizes influence on public policy through formal political channels, advocating for a cause, protests, or simply stay politically involved by voting. Scholarship covers intellectual contributions that improve conditions in communities (curricular courses; community-based research; community engaged scholarship, and blogs). Self-identity work increases personal capacity to contribute to improving community conditions. Civic professionalism / vocational choice, is engaging in a profession, career, or research that serves the public interest and has community or societal benefits.

The Center for Civic Engagement focuses on three main subjects related to its detailed definition of mission. These are: "Direct Service"; "Philanthropy and Giving"; "Activism and Advocacy". These three interactive subjects are defined as below:

Direct service is about hands-on involvement and taking action to address issues of immediate need or concern. Direct service can be one-time only projects, an on-going commitment, working with a group, or working individually. Some organizations are considered 'direct service providers,' meaning their mission is to meet people's immediate needs, such as food, shelter, clothing, or medical care. Direct service encompasses anything from visiting with the elderly in a nursing home to trail maintenance in local parks to packing food. The Center for Civic Engagement strongly encourage students to engage in an on-going basis rather than an episodic basis to allow for service work to be most meaningful for them and the community agency. Philanthropy and activism are some ways in which to get involved and help create change in a community. Philanthropy allows one to donate money, foods, household items, and/or time to 
raise money or in-kind donations to help meet community needs. One of the best ways to become more engaged in the community, being an advocate allows the students to work for changes in policy and infrastructure that can create more long-term impacts and solutions to issues of public concern. Activism and advocacy can help to provide awareness and address the root causes of community issues.

The most important function of the CCE is education-focused and is defined as "encouraging students to think about the problems in their communities and take action and responsibility as much as they are able". Even one-time projects might significantly change students' awareness and perspective regarding community engagement. Therefore, the definition of the CCE's main purpose and vision is explained with regard to civic engagement education. The CCE wants every student at Oregon State University to be able to answer and internalize following questions: "What issues do you care about? What changes do you want to see in your community/world? How will you better your community and world? How will you give back to the next generation? How will you make a difference? What will you do to build a better world?" As it is seen, OSU is working to produce civic-minded graduates and create a camps climate where all students will have the desire to be engaged in positive social change and will realize and cultivate their capacity and agency to do so.

The CCE wants to provide students with services mentioned bellow in order for its students to experience civic engagement:

Experiential learning through annual, one time, and ongoing co-curricular community service and service-learning opportunities; Educational programming to raise awareness about issues of public concern; Individual service consultation to assist students in finding service opportunities and areas of passion; Consultation for service groups and student organizations related to community service programming, service-learning education, and reflection strategies; Networking between the Oregon State University's campuses and surrounding community.

Students who engage in service-learning learn vital professional skills including critical thinking, collaboration, problem-solving, reflection, and teamwork. They learn about themselves and their community. They learn about their abilities to impact change in areas of their interest. They gain a deep understanding of social issues. They build new relationships and leadership skills. There is a large body of research that documents some of the impacts of servicelearning and community service on the development of students. Students learn about the social issues and perform projects with local non-profit and community-based organizations. For example, The Alternative Breaks which organized by CCE challenge students to critically think and react to problems faced by members of the communities in which they are involved. Alternative Breaks experience encourages students to critically analyze their assumptions and mindsets through learning about the complexity and root causes of social issues. The learning occurs for students as they are asked to be willing to engage in difficult conversations, ask questions, examine their beliefs, make mistakes, and confront challenging issues. The Alternative Break Program values holistic education and creates opportunities that inspire personal growth with focus on short-term relief in addition to long-term sustainable social change. The "Hunger and Homelessness", one of the Alternative Black Trips taking place in San Francisco, is described at CCE Website as below:

Explore the complex, multi-faceted factors at play impacting hunger and homelessness in San Francisco and learn about homelessness issues in major urban areas including the short term relief and long-term solutions that are being worked for and envisioned. Participants will complete service projects centered on addressing hunger and homelessness while meeting and working alongside local visionaries who actively address these issues in their communities.

DOT Program, carried out by the CCE, which challenges OSU community (students, faculty, and staff) to DOT (Do One Thing to better the world), is one of the significant programs that contributes to the "civic-minded graduates" aim. DOT (Do One Thing) Program informs students that individual efforts count as well, and guides OSU community on individual opportunities. Following list gives only a few of DOT opportunities found on campus and in the Corvallis community:

Commit to composting, recycling, and responsible consumer educations; Join the Natural Areas Action Team of the Corvallis Sustainability Coalition; Get trained to be an advocacy volunteer at CARDV (Center Against Rape and Domestic Violence); Organ and tissue donation awareness in high schools and in the community; Volunteer with Donate Life Northwest LGBTQ+ equality and education: Volunteer and take action with Basic Rights Oregon; Work to start additional community gardens that provide food to local food banks; Immigrant rights: Volunteer with CAUSA, Oregon's Latino Immigrant Rights Organization; Tutor or mentor at a local elementary, middle, or high school; Work with creating and promoting anti-bullying programs in schools. As it is suggested in the calls for participation mentioned 
above, DOT (Do One Thing) has been placed as an awareness project covering all areas related to civic engagement.

\subsection{How to manage relationship with communities and students}

\subsubsection{Volunteering areas focused on by CCE}

Volunteer opportunities are organized into four main issue areas at The Center for Civic Engagement: Hunger \& Poverty; Environment; Health \& Wellness, and Youth \& Education.

CCE, also, encourages students to explore other issue areas including: Advocacy and human rights; Animal welfare; Arts and culture; Criminal justice; Disaster preparedness and relief; Disabilities; Domestic violence and sexual assault; Economic justice; Educational equity and literacy; Emergency response and public safety; Faith-based; Gender issues; Global human rights; Globalization; Immigration; Land use and planning; LGBTQ+ rights; Racial justice; Seniors; and Veterans.

\subsubsection{Relationships with communities and matching with the students}

The CCE has been established in August 2011 as a follow-up organization of The Community Service Center. The CCE guides its works towards all civic engagement areas and its inheritance from The Community Service Center is being focused on community service and service-learning at present. Therefore, the CCE's relationship with other communities is quite strong due to past experiences, accumulation of knowledge, and its present network. Outreach and engagement are foundational and cornerstones for the CCE's work and mission. CCE works with 35 partners in the greater local community and had students work with about 62 different organizations including regional locations for 2013-2014. Partnerships with 56 community partners and community organizations were cultivated and maintained through CCE staff members to identify community needs and volunteer opportunities. CCE is in constant communication with local community partners to get updates needs in the areas of service, advocacy, awareness rising, and philanthropy events.

New relationships between the CCE and community organizations begin with the organization initiating contact and expressing a need to the CCE, or through the CCE hearing about a community organization and doing initial outreach via phone or a meeting. As long as the organization is inclusive of all students regardless of background or identity, the CCE works with this partner to send messages to potential student volunteers who may be interested in the opportunity. Partner relationships are maintained by two external coordinators at the CCE. External coordinators meet regularly with community partners to assess needs and keep a long-term partnership. CCE has a community partner database that manages all the information about community partners and they also post all of their opportunities on their website. Over 250 service or community opportunities posted on CCE website over the course of the year. Communities might need volunteers for one-time jobs, as well as for seasonal or long term projects. Given below is, in three domains, some of the volunteer opportunities posted on the CCE's website concerning one-time, seasonal or permanent volunteer needs.

In the newsletter published in search of volunteer teachers to work with English language learners, (Community ESOL Instructors based on public-oriented services) job description and requirements are defined as:

One-time volunteering job description for the carnival hosted by Jefferson Elementary School is defined as: The carnival at Jefferson Elementary School needs volunteers to assist with the cake walk, bounce houses, face painting, the prize room, serving cotton candy and popcorn, and carnival games.

Camp Korey Summer Camp has announced their search for volunteers to serve as cabin counselors for one week during camp with the newspaper below:

Camp Korey, just 45 minutes outside Seattle, is a non-profit camp dedicated to serving children with serious and lifealtering medical conditions. We are looking for some amazing volunteers for this coming summer of 2014. Our volunteers spend a week at Camp Korey as a cabin counselor. You'll have the opportunity to help a camper catch her first fish, get messy in our camp- wide food fight, or give a camper the encourage he needs to tackle the high ropes course.

The CCE supports programs that have philanthropic purposes, as well as programs that provide direct service. The CCE supports such programs by guiding students towards volunteering and community engagement. Students can either personally donate for these programs, or they can support them by volunteering in events. They can also plan 
events (such as campaigns) to improve motivation and raise donations, or they might work in handling the donated materials such as cleaning used clothing items, sorting them etc. In such group projects, fundraising and donation make up the two main parts.

The details of the newsletters are presented below concerning the recruitment of volunteer students for fundraising and donation events. First example is a notice posted by St. Jude Children Hospital in order to find volunteers to participate in fundraising events. The second notice is posted by the Center against Rape \& Domestic Violence (CARDV) in order to find student volunteers to collect needed donations. These newsletters are below:

St. Jude Up 'til Dawn is a nationwide student-led philanthropic program in which college students raise funds for and awareness of St. Jude Children's Research Hospital. Students participate in a year of fundraising that culminates with the Up 'til Dawn all-night challenge: find a school and register; join or start a team; set up your personal website to ask for donations; earn prizes for your fundraising efforts; stay up for good at the all-night challenge.

The mission of the Center against Rape and Domestic Violence is two-fold: to provide services and support to those affected by sexual and domestic violence, and to provide education and leadership within the community to change the societal conditions that cultivate these forms of violence. CARDV is currently in need of both monetary donations and in-kind donations. All in kind donations should be new and unopened. Most needed items fall into the following categories: personal care items; household items; children's items; office supplies.

The Center for Civic Engagement supports communities that are focused on activism and advocacy in their needs for recruiting volunteers or student members. These communities can be local organizations as well as independent student organizations. It is found the newsletter examples posted by the Ceasefire Oregon Education Foundation and RESULTS in order to find volunteers and members. These two newsletters are below:

The Ceasefire Oregon Education Foundation works to reduce gun violence by educating the public and providing opportunities to dispose of unwanted firearms. Volunteers can get involved in gun turning, distributing information to the public, and more.

The RESULTS mission is to create the public and political will to end poverty by empowering individuals to exercise their personal and political power for change. They combine the voices of passionate grassroots activists with strategic grass-tops efforts to leverage millions of dollars for programs and improved policies that give low-income people the health, education, and opportunity they need to thrive. RESULTS focuses on three areas of advocacy: global health, global education, and micro finance and economic opportunity. RESULTS works on both domestic and global poverty issues. Consider participating in an activist skill building training.

When newsletters concerning direct services, philanthropic and activism areas are examined, it can be concluded that postings by communities that provide direct services are of relative majority, followed by philanthropy and giving, and activism and advocacy areas. One of the reasons for this is due to the fact that providing direct services is a more common work area as an old area of civic engagement.

\subsubsection{Working with students as a staff or a volunteer}

The Center for Civic Engagement serves as a major student hub managing projects not only with volunteer students but also with its part-time student staff. OSU students can volunteer or work as student staff in the Center, as well as making use of internship opportunities. Out in the community, the projects are managed by student leaders who are trained by CCE, professional staff, and CCE student staff. There are 7 student staff members, 2 graduate student workers, and 1 professional staff member in the CCE who support students on the large days of service. Other student leaders and staff members are also recruited to assist with this. CCE student staff positions fall into three categories: Internal Coordinator, External Coordinator, and Marketing \& Communications Coordinator. The Internal Coordinators primarily plan and implement service days and civic engagement programs as well as develop partnerships with on campus units and organizations. Internal Coordinators liaise with campus groups like student organizations, Greek chapters, and residence halls. The External Coordinators build, cultivate, and maintain campus-community partnerships and identify community needs and volunteer opportunities. The Marketing \& Communications Coordinator creates the CCE weekly newsletter, maintains CCE social media, and helps to do visibility and marketing work for the CCE events.

The CCE both plans days of service and offers individual consultations for students looking to volunteer independently. For days of service, students must register through an online web form, confirm their attendance, and sign a volunteer service form along with any other forms that the community organization may require. These aspects of registration are a responsibility the internal coordinators who is the primary planner of the event and the service site 
leader, who is most typically a CCE staff member. Also, independent volunteers are welcome to come to the CCE for an individual consultation to assess their interests in volunteering. Most student organizations that volunteer are independent and student-led.

CCE is a resource to connect students to volunteering in the local community. In this sense, the CCE is the central volunteering hub for student affairs. CCE posts one time and ongoing volunteer opportunities and primarily serves student affairs. The second one is that CCE encourages students to get involved in improving their community through philanthropy, activism, and countless other civic engagement activities. CCE hosts events and programs that aim to build community among students and Oregon State University community members as well as within the larger Corvallis (Oregon State University's home town) community. Third, increasing participation in programs managed by the CCE. Also, CCE plans days of service and offers individual consultations for students looking to volunteer independently. For days of service, students must register through an online web form, confirm their attendance, and sign a volunteer service form.

Students can get involved in one-time events, ongoing service, or day long or week long community-based service-learning experiences through the CCE. Some are heavier on the service some are heavier on the learning. All meet community identified needs. There are no prerequisites or selection process (such as interviews or tests) in order to participate in the projects in communities or programs by the CCE. All projects in civic engagement area are open to all OSU students. However, some organizations have requirements of their volunteers relating to age, experience, or ability depending on the nature of the work that they require. When this is the case, the organization will implement its own application process or form to be signed. The CCE seeks to include all students in volunteer activities and therefore places no requirements outside those of the community organization. Factors that increase diversity is, indeed, favored since students from different schools with different cultural background and skills would enrich the volunteering activities. For example, one huge advantage of working with international students is the chance to share a broader scope of the Corvallis (OSU's hometown) community with them along with the culture of volunteering. There is not a formalized structure for volunteering that takes place within coursework and student affairs. Participating in volunteering activities help students gain experience; however, it does not grant any extra credit or scholarships. The more universal advantages of engaging in service include critical thinking skills, problem-solving, and broadening one's horizons, which may have an academic advantage. There may be studies that express a relationship between volunteering and academic achievement. It certainly gives graduates an advantage in future endeavors and is a great addition to resumes and CVs. It is absolutely important to students to provide themselves with as many opportunities and advantages as possible.

One of the biggest hardships of working with student volunteers is to maintain consistency. In order to overcome this, CCE encourages students to think critically about the impact of their service and ways in which they can shift from short-term efforts to long-term systematic change. Another huge factor in volunteer retention is appreciation. CCE strives to give volunteers a positive experience in days of service and then to express gratitude as well as express the importance of the work that they do. This encourages volunteers to remain engaged in their community and continue their great work. Therefore, CCE is looking at ways to connect the out of classroom/co-curricular service work with academic affairs and service-learning to try to provide more continuous service to community partners.

Student volunteers are engaged in both a pre- and post-project reflection session. The session before is often to frame the purpose of the session, break ice between groups, get students thinking about the purpose of their work, and debriefing students on respect guidelines when entering the community. The reflection session gets students to analyze the impact of their work and to encourage students to dedicate themselves to long-term change instead of one-time service activities. Many community organizations do their own orientation and training as well.

Also, CCE supports some events such as Annual Nonprofit \& Volunteer Fair, Earth Day, and Day of Caring Service. These events are so important because students have opportunities to meet representatives from local and national nonprofit and government organizations representing who are seeking OSU volunteers, interns, and employees in public service and non-profit fields. It could be referred 'Day of Caring Service' for describing effects of these event. For 2014 Day of Caring Service, student volunteers helped to repair of single home of elderly resident while washing the sides of the house and scraping old paint off siding to prepare for painting during a Home Restoration project with Habitat for Humanity. Volunteers removed old and water-damaged boxes from basement, compost old plants, folded 16 rolls of paper towels for restrooms. Volunteers made 24 bracelets to contribute to Corvallis-Gondar Sister Cities Association's friendship bracelet project to send to students of Gondar, Ethiopia during our on-campus Craft 'N Care project. 


\section{Conclusion}

The relevancy of education can be increased through be placed based and taking place within real world contexts and students agency can be cultivated through experiential learning in community that is connected to academic learning. In order to deliver on their public purpose, universities and institutions of higher education are increasingly creating infrastructure for volunteer, civic engagement, and other forms of community engagement in and outside the classroom. Universities can send the message that what happens in the world matters to their students and society through integration of volunteering, service-learning, and other forms or public engagement into teaching, research, and scholarships activities.

\section{References}

Fleur de Lys C. (2006). Learning for life: creating endless possibilities in secondary education. Seameo Innotech International Conference, 15-17 November 2006, Diliman (Quezon City), Philippines.

Fischer, L. \& Banister Schaffer, K. (1993). Older volunteers, a guide to research and practice. California: Sage Publication.

Giroux, H. (2009). Cultural studies, critical pedagogy, and the politics of higher education. In R. hammer \& D. Kellner (Eds.), Media I cultural studies: critical approaches. (pp.88-106). New York: Peter Lang Publishing.

Handy, F., R. A., Cnaan, Hustinx, L. \& others (2010). A cross-cultural examination of student volunteering: Is it all about résumé building?. Nonprofit and Voluntary Sector Quarterly, 39 (3), 498-523.

Hustinx, L., Handly, F. \& others (2010). social and cultural origins of motivations to volunteer. International Sociology, 25 (3), 349-382.

Jacob, B. (2009). Civic engagement in higher education: concepts and practices. USA: Jossey-Bass.

Marullo, S. \& B., Edwards (2000). Service-learning pedagogy as universities' response to troubled times. American Behavioral Scientist, $43,746-755$.

Menchik, P. L. \& Weisbrod, B. A. (1987). Volunteer labor supply. Journal of Public Economics 32(2), 159-83.

Meier, S. \& Stutzer, A. (March 2004). Is volunteering rewarding in itself. IZA Discussion Paper, No. 1045.

Naylor, H. (1973). Volunteers today, finding-training and working with them. USA: Dryden Associates.

Penner, L. A. (2002). Dispositional and organizational influences on sustained volunteerism: An interactionist Perspective. Journal of Social Issues, 58, 447-467.

Sergent, M. T. and Sedlack W.E. (1990). Volunteer motivations across student organizations: A test of person-environment fit theory. Journal of Collage Student Development, 31, 255-261.

Smith, D. H. (1981). Altruism, volunteer, and volunteering. Journal of Voluntary Action Research, 10, 21-36.

Süngü, H. (2008). Yüksek öğretimin Avrupa Birliği politikalarına girmesi ve genişlemesi. Bilim, Eğitim ve Düşünce Dergisi, 8/2.

Thomas E. (2000). Civic responsibility and higher education. USA: American Council on Education/Oryx Press.

Tilly, C., \& Tilly, C. (1994). Capitalist work and labor markets. in N. J. Smelser, \& R. Swedberg (Eds.), Handbook of economic sociology (pp. 283-313). NJ: Princeton University Press. 
